\title{
En uvanlig årsak til svelgevansker
}
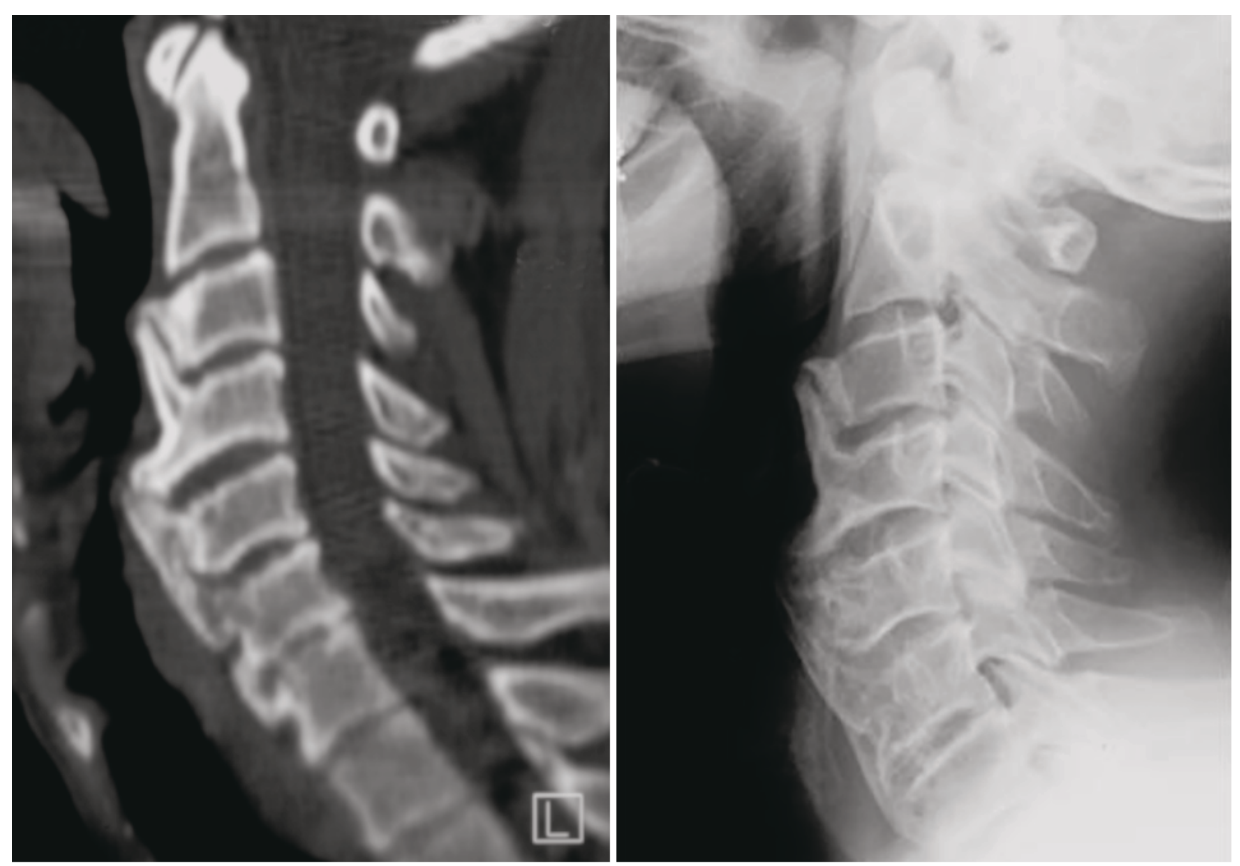

Forestiers sykdom, også kjent som diffus idiopatisk skjeletthyperostose (DISH), er en ikke-inflammatorisk tilstand karakterisert av forbeining av ligamenter (1). De fleste tilfellene er enten asymptomatiske eller medfører innskrenket bevegelighet og smertefull stivhet. Når sykdommen rammer cervikalcolumna, kan virvlene i uttalte tilfeller bli mer enn fordoblet $i$ anteroposterior diameter og føre til dislokasjon av strukturene på halsen. De mest alvorlige symptomer er luftveisobstruksjon og svelgevansker på grunn av kompresjon av luftrør og spiserør (2).

Sykdommen rammer flest eldre menn og resulterer i ossifikasjon, først og fremst av det fremre longitudinelle ligamentet i columna. I motsetning til ved ankyloserende spondylitt (Bekhterevs sykdom) er mellomvirvelskivene intakte. Per definisjon skal minst fire virvler være affisert, med beinbroer imellom. Etiologien er ukjent, men tilstanden er assosiert med metabolske forstyrrelser som overvekt og diabetes mellitus type 2 .

Illustrasjonen viser CT-bilde med rekonstruksjon. Det gir den beste fremstillingen av forandringene. Røntgen cervikalcolumna viser beinete påleiringer på halsvirvlene.
Funksjonsbilder med bøy og strekk kan vise innskrenket bevegelighet.

Pasienter som har store vanskeligheter med å ta til seg fast føde eller har luftveisobstruksjon, bør opereres med tilgang via et lengdesnitt på halsen. Den unormale beinsubstansen fjernes med bor og tenger inntil normal størrelse på virvlene er gjenopprettet. Som ved alle fremre retrofaryngeale tilganger er det en risiko for $n$. recurrens-parese. Den mest fryktede komplikasjonen er imidlertid ruptur i spiserøret og lokal infeksjon eller senkningsabscess til thorax. Faren er betydelig større enn ved annen kirurgi på grunn av den markerte deformeringen og kompresjonen av spiserøret fra osteofyttene. Langtidsoppfølging etter kirurgisk behandling er sparsomt beskrevet i litteraturen, men risikoen for residiv er trolig liten. Det er derfor ikke nødvendig med oppfølging - utover å følge opp vedvarende dysfagi.

Siden de fleste med Forestiers sykdom er uten symptomer, er tilstanden underdiagnostisert. Leger, og spesielt øre-nese-hals-spesialister, bør kjenne til tilstanden som en differensialdiagnose ved svelgeproblemer hos eldre. Den vil være kjent for noen, siden den også rammer hunder. Spesielt rasen bokser er utsatt.

\section{Jon Berg-Johnsen}

jon.berg-johnsen@rikshospitalet.no

Nevrokirurgisk avdeling

Oslo universitetssykehus, Rikshospitalet

Det medisinske fakultet

Universitetet i Oslo

Jon Berg-Johnsen (f. 1955) er ph.d., overlege og professor i nevrokirurgi.

Forfatter har fylt ut ICMJE-skjemaet og oppgir ingen interessekonflikter.

\section{Litteratur}

1. Forestier J, Rotes-Querol J. Senile ankylosing hyperostosis of the spine. Ann Rheum Dis 1950; 9: $321-30$

2. Verlaan JJ, Boswijk PF, de Ru JA et al. Diffuse idiopathic skeletal hyperostosis of the cervical spine: an underestimated cause of dysphagia and airway obstruction. Spine J 2011: 11: 1058-67.

Mottatt 15.4. 2014, første revisjon innsendt 1.8. 2014, godkjent 25.9. 2014. Redaktør: Hanne Støre Valeur. 